\title{
Towards Tawang Station Area as Smart Urban Railway Space
}

\author{
Nurma Mediasri Huwaida*, Agung Nugroho, Reivandy Christal Joenso \\ Departmen of Architecture, Faculty of Engineering, Diponegoro University, Semarang, Indonesia
}

*Corresponding e-mail: nurmamh@gmail.com

\author{
Article info: \\ Received: 19-04-2020, Revised: 30-04-2020, Accepted: 04-05-2020
}

\begin{abstract}
The purpose of this research is to analyze the possibility of implementing Smart Urban Railway Space concept in the development of Semarang Tawang Station area which is one of the entrance gates of Semarang tourists and has a high historical value. The area of Tawang station becomes an integral part of Semarang Old Town because of its adjacent location. This attachment is one potential that can be considered to grow the activity of the area into a tourism area and a business center. In the last 2 years in the city of Semarang, the number of visitors and users of public transport increased annually. Increasing number of visitors can cause overcrowding. The crowded situation of visitors caused the lack of circulation so that the need for redesigning Tawang station area. A station area (public transportation) must be able to adapt to the environment and function needs for the visitor. Smart city design is about rethinking infrastructure, buildings and facilities as well as other infrastructure integrated to form smart cities and smart urban space. Smart Urban railway space is a concept that integrates an architectural building with the surrounding open space. It is hoped that Smart Urban Railway Space concept can parse overcrowding and make the area of Tawang station a potential tourism area. Methods used are qualitative methods with a rationalistic approach. The result of this research is a recommendation of the Smart Urban Railway Space concept at Tawang station area which is expected to parse the overcrowding problem that occurred.
\end{abstract}

Keywords: Tawang station area, Semarang, overcrowding, smart urban railway space, tourism

\section{Introduction}

Semarang is one of the cities that connect between cities and islands in Java. Semarang is also one of the most important cities in improving the economy in Central Java because of its strategic geographical position. This strategic condition provides opportunities for the development of city activities in the tourism sector (Meytasari \& Tisnawati, 2018). The existence of infrastructure such as ports, airports and stations make the city of Semarang a regional transit city in Central Java. Tawang Station is one of the stopping points of the train that becomes the gateway of tourists to the city of Semarang. Tawang Station is not only a gateway of tourists, but also an origin and destination of the city's transportation.

The city is developing very rapidly as a result of accepting and accommodating migrants, passengers and visitors from the tourism sector. People think that the city of Semarang is only dubbed as tourist Transit City, it is certainly one of the driving factors for the government to develop the tourism sector to be better and known by the wider community (Pinasthika \& Pradoto, 2018). Tourism is a potential sector that can support the progress of a city. Tourism development provides many advantages for a city. Most people think that tourism is good for increasing the city's economy and adding jobs and developing local community businesses. A city that has good tourism potential and can maximize the potential, thus beneficial for the improvement and development of a city (Sukawi, 2008).

The city of Semarang has several public transportation alternatives as a means of supporting tourism, trains are one of them. The number of public transportation users in Semarang each 
year is increasing in every sector (Dinas Perhubungan Kota Semarang, 2018). Users of the train's public transport annually increase around $2 \%$ (see table 1). Most of the people who live in the city and often use the public transportation facilities feel the situation is uncomfortable due to overcrowding in certain times (Mackingtosh et al., 1975).

Table 1 Public Transport User 2015 - 2018 in Semarang

\begin{tabular}{|l|r|r|r|r|}
\hline & \multicolumn{4}{|c|}{ Year } \\
\hline $\begin{array}{l}\text { Number of } \\
\text { public transport } \\
\text { users }\end{array}$ & 2015 & 2016 & 2017 & \multicolumn{1}{|c|}{2018} \\
\hline - Bus non BRT & 4.415 .468 & 4.503 .777 & 4.593 .853 & 4.685 .730 \\
- Bus BRT & 8.023 .869 & 9.787 .580 & 11.551 .875 & 12.875 .625 \\
- Train & 3.681 .740 & 3.755 .375 & 3.830 .482 & 3.907 .092 \\
\hline - Ship & 157.874 & 161.031 & 164.252 & 167.537 \\
- Air Plane & 3.782 .087 & 4.055 .378 & 4.328 .669 & 4.601 .960 \\
TOTAL & 20.061 .038 & 22.263 .142 & 24.469 .131 & 26.237 .944 \\
\hline
\end{tabular}

(Source: Department of Transportation, Semarang City, 2019)

Public transportation will become an attraction if it meets the needs of its users. This means that a public transportation must have adequate capacity especially in the peak period of visitors ' arrival. Failure to provide efficient public transport system means that it will cause overcrowding. Popp (2012) argues that tourist areas that may experience negative crowds (in very crowded conditions that make visitors feel less freely moving due to the lack of his private space) and positive crowding (in situations where crowding can add to the visitor experience). Weber et al. (2017) also emphasized that although crowding can sometimes be regarded as a sign that the attraction is worth a visit, which makes positive impressions/connotations, and negative crowding is a surplus of density to a tourism object. The negative crowding can be a major problem in the tourism aspect of a city. In such contexts, that the density/distress felt due to too high number of tourists will cause urban mobility problems.

Crowding usually refers to the psychological response of people to density. Overcrowding here is described as a result of increased intensive use of a public space with limited capacity, which is regarded as a disruptor of the visitor convenience of activity (Gerritsma, 2019). Overcrowding is one of the main problems affecting the city, and not only is due to tourists who are dating feel the sense of tightness/discomfort, lack of privacy as well as the occurrence of unwanted interactions of psychological distress (Crothers et al., 1993; Ellisa, 2016; Gove et al., 1979; Jazwinski, 1998). Overcrowding is not just an urban problem. It is also a real form of transportation problems that become the gate of a crowded tourism destination at a certain time especially when peak arrivals of tourist (House of Commons Transport Committee, 2003). Problems that will arise when there is overcrowding due to transportation that not accommodated properly is the occurrence of transportation.

Tawang Station is one of the stopping points of public transportation of land lines. As a historical colonial heritage town, it should be the area of Tawang station can be a strategic tourism location. In the last 2 years, the number of tourism visitors travelling in the city of Semarang increases annually (Badan Pusat Statistik, 2019). Each year the visitor increase is about $14 \%$ (see table 2). If the increase in visitors is not in anticipation well there will arise problems of the vehicle in the road, when the land from Tawang Station area is no longer able to accommodate the number of visitors due to overcrowded. 
Table 2 Number of Tourist in Semarang

\begin{tabular}{ccc}
\hline & $\mathbf{2 0 1 7}$ & $\mathbf{2 0 1 8}$ \\
\hline Foreign Travelers & 59.672 & 66.105 \\
\hline Local Travelers & 4.964 .804 & 5.703 .282 \\
\hline TOTAL & 5.024 .476 & 5.769 .387 \\
\hline \multicolumn{2}{c}{ (Source: Central Bureau of Statistics, Semarang City 2019) }
\end{tabular}

A station area or public transportation must be able to adapt to the environment and function needs for the visitor. The increasing needs of Rail transit with high passenger capacity and high efficiency are also one of the triggers of increasing the need for transportation room infrastructure for urban area tourism (Galiza et al., 2009). Station Plaza is a public space in the station area that can provide urban open space needs, improve the city identity, improve communication activities in the community, improve the quality of life of people who live near the station and contribute to the development of tourism (International Union of Railways, 2017).

The current smart city development trend is to provide new functions, especially in terms of local communities and to create public open spaces that can attract and become tourism places. Smart city by Giffinger, Fertner, Kramar, Meijers, \& others (2007) has 6 characteristics including smart economy, smart mobility (smart lighting, smart infrastructure), smart environment, smart people, smart Living, smart Governance (smart license). Smart city design is about rethinking infrastructure, buildings and facilities as well as other infrastructure integrated to form smart cities and smart urban space. The purpose of this research is to formulate the design concept of Semarang Tawang station area as smart urban railway space so that it can function optimally and become tourist attraction of Tawang station area.

Semarang City with its nickname "Semarang Hebat " has implemented some smart city concept, one of which is smart tourism (Sanjaya, 2018). The concept of smart tourism or smart tourism is the concept of development of tourism sector which is being developed in the last years by following the development of information technology. Fundamentally, the concept of smart tourism has three characteristic which is (1) presenting the merger of tourism industry with information and communication technology, (2) is social with social interaction between tourists and local residents, and (3) there is a connection between various related stakeholders. The concept of smart tourism emerged as a derivative of smart city development concept.
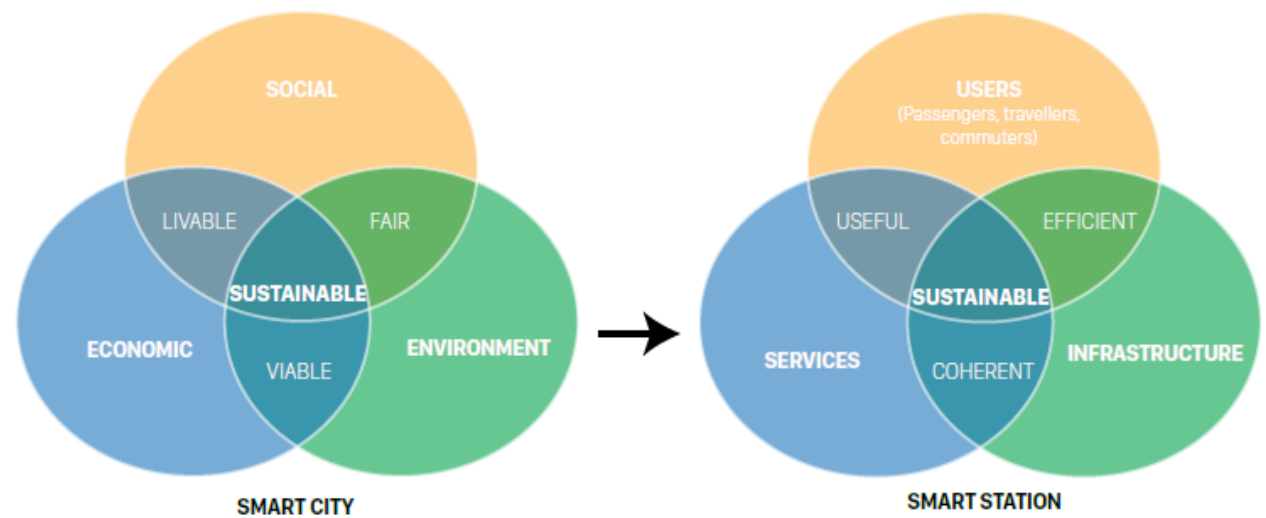

Figure 1. Implementating smart city concept into Smart Station (Source: UIC, 2017) 
The criteria used to define smart tourism in the smart city concept can also be used for a station area (see Figure 1). The station area has a unique characteristic in terms of function, location, service and use, both in terms of time and space (Australian \& Audit, 2019). Smart stations are designed to cover the surrounding environment and integrate with Smart city. This research is focused to make the area of Tawang Smart Urban railway space in the long run will provide better and safer environment and integrated with Smart city. The Smart Urban Railway space is about the potential of an area to ensure that a public space can be integrated and become more than just a simple public transportation area. This indicates that the area of Tawang station must be a public space that innovates, according to local peculiarities, that can add extra value to the concept of smart tourism.

Tokody, Schuster, \& Papp (2015) defines a smart urban railway space concept by integrating an architectural building with its surrounding open space (Architecture and public space), integrating Movement/circulation (Smart Mobility/Integrated Mobility), and adapt to meet the needs of the Adapting to all station users. The 3 main aspects of Smart Urban Railway Space are:

- Architecture and public space

Station stations in the cities have the economic potential and the management of the stations must be in a position to be able to exploit this makes the station as the foundation for the local economy. The Smart Urban Railway Space should not be a burden to the surrounding environment. The term ' environment ' encompasses ecology, society, culture, and urban environment, but also the functional environment of the station. The Smart Urban Railway Space shouldn't be a source of conflict, but it must help resolve any tension that may be a legacy of its history.

\section{- Smart Mobility/integrated mobility}

The station is an important hub for transportation. Whether in a large urban environment or in rural areas, the station forms a focal point for at least one other mode of transport: the car. In urban areas, the station is also often a meeting point for up to three or four other modes of transportation (especially cars, or vehicles driven, buses, bicycles, trams, metro, Mass Rapid Transport, electro mobility and pedestrian cars). Smart mobility is about offering more sophisticated and more advanced options in mobility between modes. The station is part of an organized urban environment and is increasingly regarded as a public space and expansion to the city. Consequently, the new station design must connect city planning and infrastructure development of rail transport.

- $\quad$ Adapting to all station users.

The Smart Urban Railway Space concept meets adapting challenges for everyone. The Station is designed to ensure the smooth operation of various activities and can be adapted to any changes that may occur in it. The concept of Smart Urban Railway Space takes into account the needs and expectations of various stakeholders and station users

\section{Methods}

This research uses analysis on urban elements such as: location and sites, building mass, access, circulation, function and preservation of buildings to find the potential Tawang Station area. The study used a descriptive qualitative method by describing a field phenomenon that occurred to analyze existing potentials (Furchan, 2004). Using a rationalistic approach which uses common sense as a benchmark in analyzing a problem. Rationalism is one of the traditions of philosophy that leads to the truth/fact of the field that becomes the primary source of knowledge. Thus, Tawang station area potential is then re- 
analyze with Strength Weakness Opportunity and Treat to add value to this region. By using Smart Urban Railway Space concept to developing Tawang station area so it can become a potential for the development of a faster, more effective region. Tawang station area integrated with the challenges faced by the city and the area of station Tawang becomes the tourism area of rail transport and polder park.

\section{The scope of research}

The scope of the research is located in the area of Tawang station including Tawang station, the Tawang polder, and the Kotalama building in the Merak street corridor (see Figure 2). Location boundary:

- Northern boundary : Tawang Station

- Eastern boundary : PT KAI Residence

- Southern boundary : Kota Lama Semarang

- West boundary : :Mpu Tantular Street

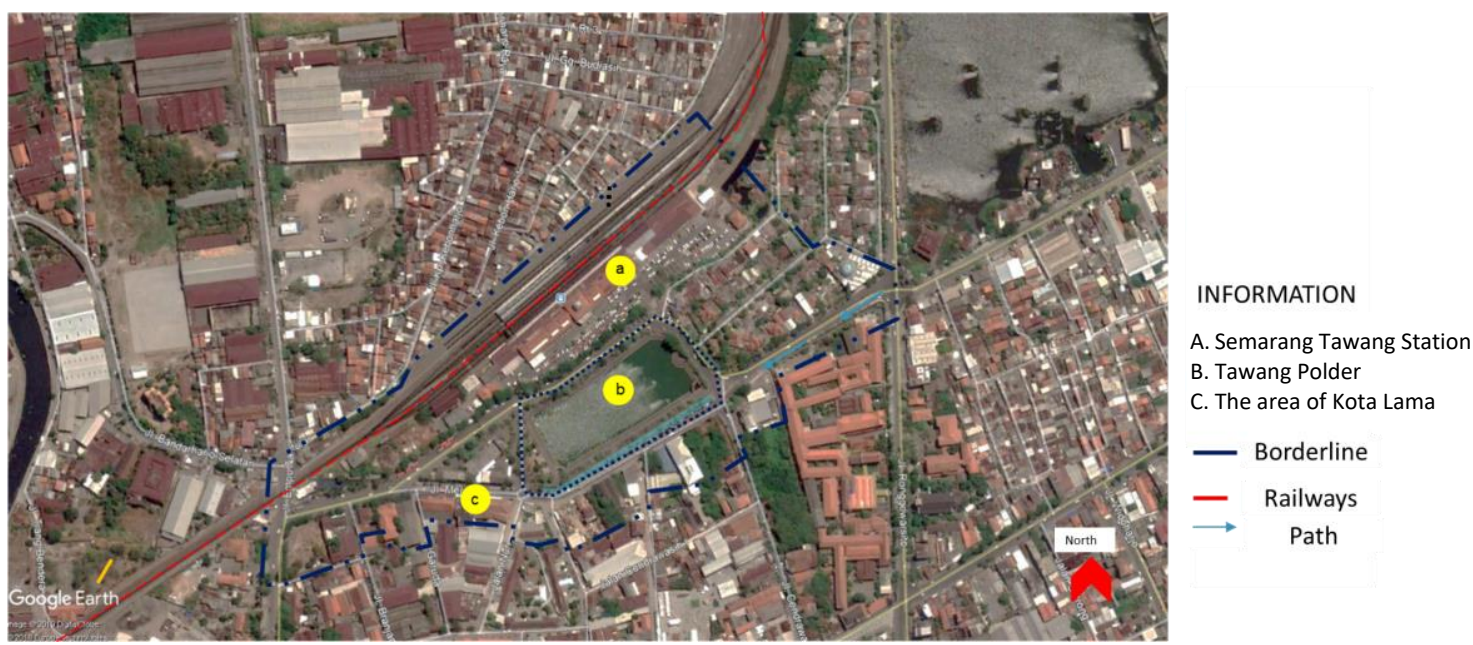

Figure 2. Maps of Stasiun Tawang Area

\section{Discussion}

\subsection{The potential in Tawang station area}

The potential of the Tawang Station Area was analyzed using the criteria of the design element of the city of Shirvani (1985) which was divided into 8 elements:

- Land use

The land in the Tawang Polder area is divided for some land functions, namely: for stations, playgrounds, polder, street vendors locations, housing for station staff, and shops (see Figure 3). 


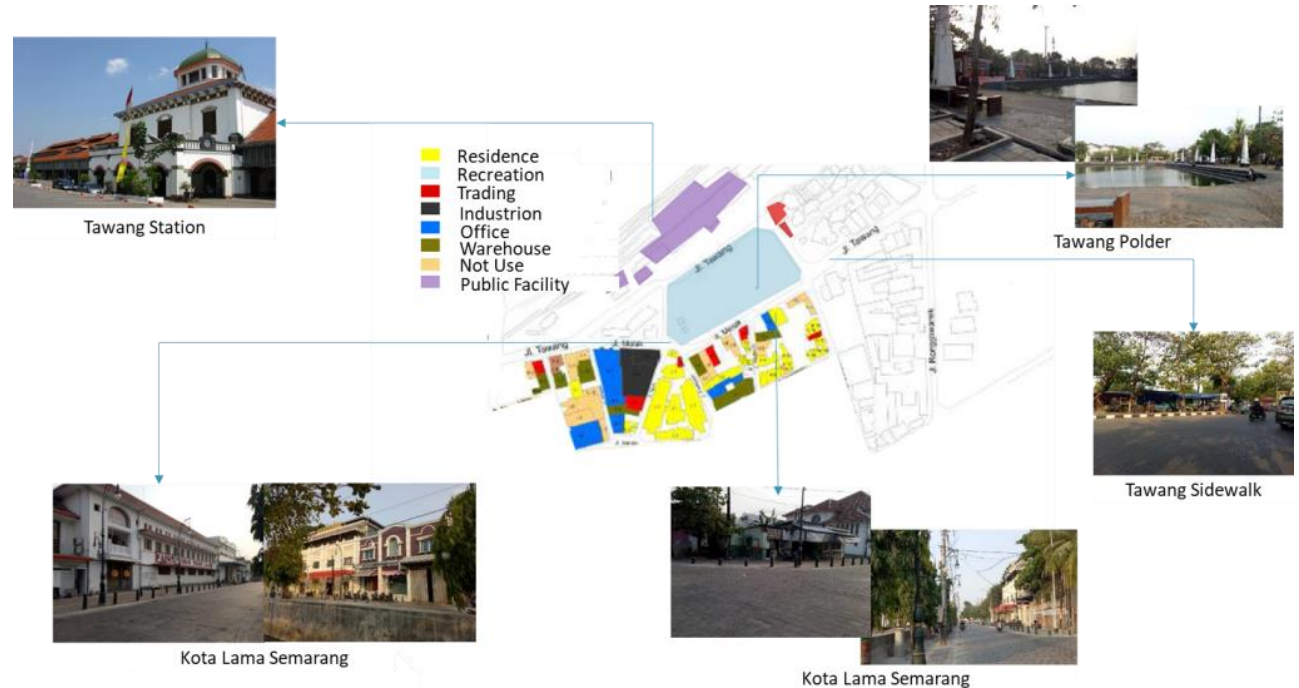

Figure 3. Land Use in Station Tawang Area

- $\quad$ Building Form and Massing

The view from the direction of Tawang has shown the rhythm of buildings. Differences in shape and altitude of buildings led to the formation of building rhythms. So, it does not make boredom when viewed and enjoyed (see Figure 4). In addition, building buildings in this area have similarities in the style of colonial buildings depicting the visual image of the Old City Semarang

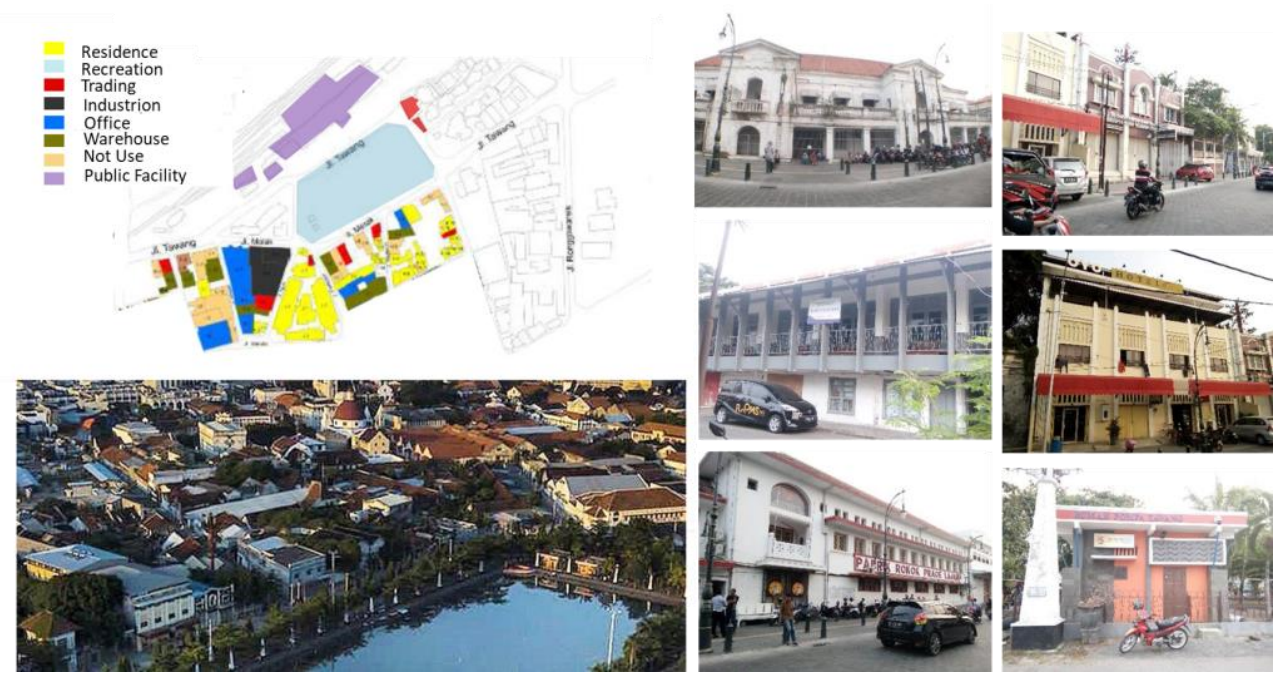

Figure 4. Building Form and Massing in Station Tawang Area

- Circulation and parking

The common problem is that the needs of passengers in accessing non-train public transportation cannot be accommodated properly so that there is a public transportation on the road agency when the land from the Tawang station area is no longer able to accommodate existing public transportation. In certain hours, passengers have a surge of arrival and departure. The circulation of current passengers is subjected to thrust and irregularities (Nugroho \& Khadiyanta, 2015).

The presence of high circulation flows and the vehicles crowd at certain hours resulted in the parking space available not able to accommodate vehicles (see Figure 
5). The irregular on street parking system on the road body resulted in disrupted transportation pathways and potentially decreasing the visual quality of the area. Less integrated parking, both station oriented and recreational facilities
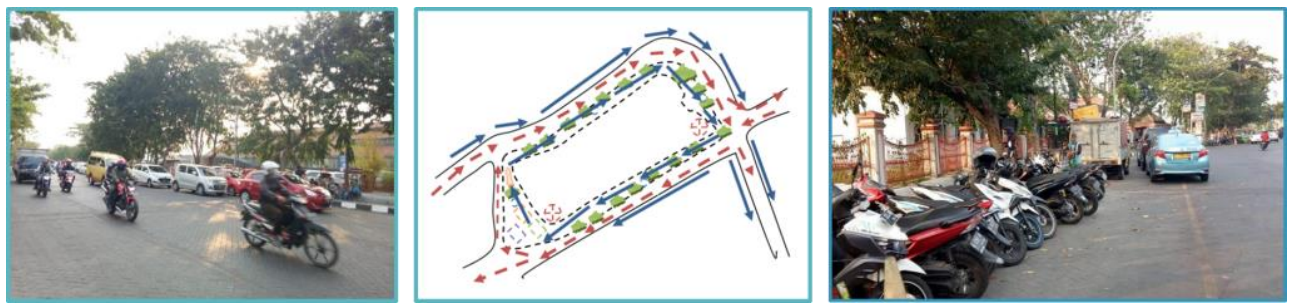

Figure 5. Circulation and Parking in Station Tawang Area

- Open space

The Tawang Polder can be an open space that offers wide views from various sides. The hygiene factor in the current polder is a top priority, if the cleanliness of the polder is still the same as the moment visitors will hesitate to stopover even if only just unwind. The Polder can be a spot for visitor attractions, especially from the direction of the station which is a means of transport (see Figure 6).
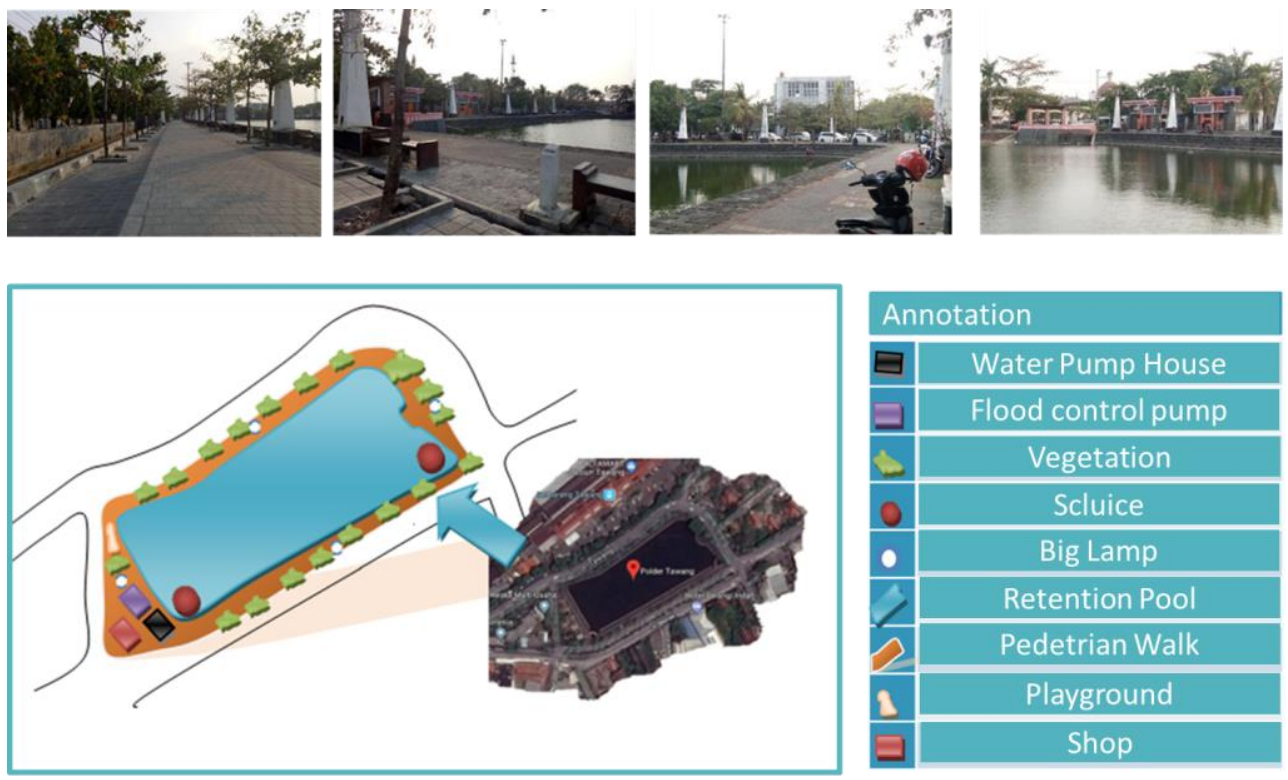

Figure 6. Open Space in Station Tawang Area

\section{- Pedestrian ways}

Pedestrians are available. The barriers that are in this pedestrian are the lack of a shade care for pedestrians. With a strong sun condition, the of elements shade becomes a very important factor to attract visitors. No or lack of road shades make the most of the visitor, be a sting and lazy down the pedestrian polder that has been available.

- Activity support

Activity support facilities are a very important part of the development of the region. In the Tawang Polder area, there are several supporting facilities that can provide benefits in the development of this region. Tawang Station is an important asset for the region, because the number of passengers per day is a tourism development target for the region. When the management of this area can attract attention, it is not 
possible that many passengers who take a car to relax for a while in the area around Polder

\section{- Signage}

Signage is a source of explanation. With the signage, it is hoped that the area users can understand the information needed. The presence of signage should be noted, because when not well placed, signage can damage the image that is already formed. Among some of the signage that is around the Tawang Polder, only the traffic signs can be seen remotely. The marking is not maintained nor is it located in a good place.

\section{- Preservation and Conservation}

Based on the results of the survey, the buildings in this area are still few conservations. The use of existing buildings in this area is still limited. Tawang Station is one of the conservation buildings that is still preserved until now, although it has undergone several adjustments of the increase of the ground face from tidal flood. There are also some hotel buildings or family mess has undergone a change because it may adjust to its function as a hotel that will look more interesting without changing the original shape of the building because all the buildings in the old City Semarang protected by conservation laws

\subsection{Development plan of Tawang area by PT KAI}

The area of Tawang station is a land owned by PT KAI. The government cannot intervene much of the change in this region. However, PT KAI itself has considered the development of this area to break down the frequent overcrowding and optimize for poorly maintained areas. The development of the area of Tawang station by PT KAI is covering the area of Tawang station, the Tawang Polder and housing PT Kai. Because there is often overcrowding on the road section of Tawang station, the party of PT KAI considers to privatize these roads as a circulation area and parking Tawang station (see picture 7). Restoring the road to the station is a concept of early train station, once the road is parking area and open space owned by PT KAI. In the development plans of the Tawang Polder, which used to be a public space, becomes a private open space of visitors to the station. It is aimed the handler's polder which was previously poorly maintained can be controlled, cleanliness polder is maintained. 


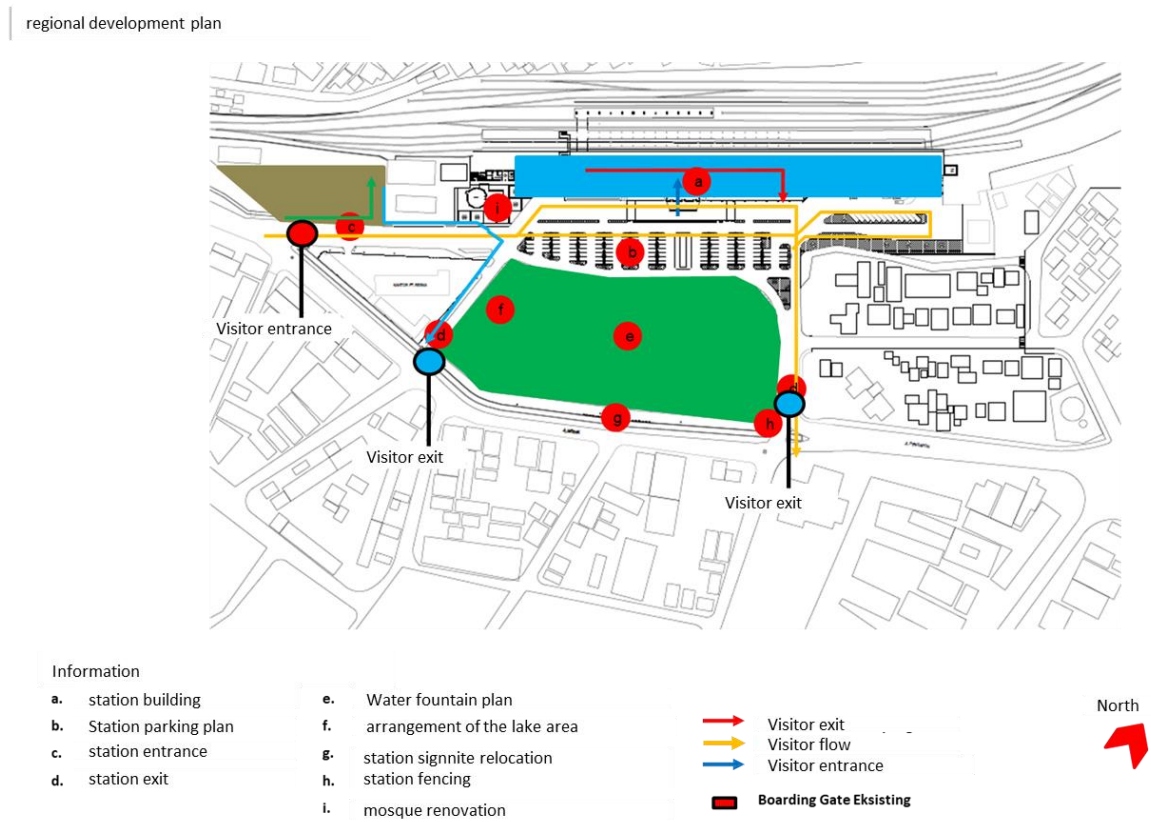

Figure 7. Expansion Plan of Stasiun Tawang area (Source: PT KAI, 2018)

This development plan raises the pros and cons for society as well as practitioners and academics. Although it aims well that the polder area can be controlled hygiene and safety, the community and practitioners are less agreed with the privatisation of the Tawang Polder which is a public space that can be the activity support of Tawang Station area. In addition, it has become a means of recreation/tourism for the people and tourists who come. With the privatisation of the area polder, the community felt unfair and it was difficult to access the polder. While the plan to transfer the section of $\mathrm{Jl}$. Tawang is a public area belonging to Tawang station supported by practitioners, academics and society with some considerations that is, solving the frequent overcrowding problems and placement of relocation of traders and taxi drivers in the road (see table 3 ).

Table 3. Interview about Development Plan in Tawang Area

\begin{tabular}{|c|c|c|c|c|}
\hline & & $\begin{array}{c}\text { BUILDING UNITS } \\
\text { PT. KAI }\end{array}$ & ACADEMIC & USER \\
\hline $\begin{array}{l}\text { TAWANG } \\
\text { STATION AREA } \\
\text { NOW }\end{array}$ & 2. & $\begin{array}{l}\text { The parking lots of } \\
\text { each vehicle still look } \\
\text { irregular. } \\
\text { The crossing from } \\
\text { Tawang Station to the } \\
\text { polder is not good, it } \\
\text { still looks dangerous } \\
\text { because there is no } \\
\text { area for crossing } \\
\text { people }\end{array}$ & $\begin{array}{l}\text { 1. The overall design of } \\
\text { the Tawang area is } \\
\text { architecturally good } \\
\text { by preserving the } \\
\text { colonial building style } \\
\text { 2. There are some } \\
\text { potential areas that } \\
\text { should be developed. }\end{array}$ & $\begin{array}{l}\text { 1. Comfortable and the } \\
\text { facilities are already } \\
\text { enough to } \\
\text { accommodate visitor } \\
\text { activities, but the lack } \\
\text { of cleanliness } \\
\text { 2. Lack of maintenance } \\
\text { and already damaged } \\
\text { infrastructure } \\
\text { (perforated roads) are } \\
\text { not immediately } \\
\text { repaired }\end{array}$ \\
\hline
\end{tabular}




\begin{tabular}{|c|c|}
\hline $\begin{array}{l}\text { PLANNING OF } \\
\text { CHANGES IN } \\
\text { TAWANG } \\
\text { STATION AREA }\end{array}$ & $\begin{array}{l}\text { 1. Closing Tawang road } \\
\text { and converting the } \\
\text { area into a parking } \\
\text { area (returning the } \\
\text { Tawang as before). } \\
\text { 2. Changed the design } \\
\text { of Polder Tawang to } \\
\text { be exclusive to PT } \\
\text { KAl which is one with } \\
\text { the tawang station. }\end{array}$ \\
\hline
\end{tabular}

PROPOSALS IN THE FUTURE

1. The street vendor area is clean.

2. Other means of public transportation (motorcycle taxis, taxis, tricycles) become centralized and more organized.

3. Making the polder area into a unity with the station

Agree with the
acquisition of the
function of the
Tawang road into a
parking area.
Disagree with the
change to the Tawang
polder which is
exclusive to Tawang
Station and expect the
polder area in the
redesign to be more
interesting

1. Not agree with the closure of the Tawang road because it will trigger a traffic jam.

2. Not agree with the development plan by PT. KAI because it seems exclusive is only intended for visitors to the station, so it is expected to be still open to the public.

1. Addition of supporting 1. Concentration of activities in the form of commercial areas or non-profit public spaces. supporting areas (street vendors, food stalls) so as not to seem dirty,

2. Upgrade Tawang polder with additional activities and facilities.

2. Regional security support facilities such as CCTV at the crossing point.

3. Better vehicle parking.

\subsection{Strength, Weakness, Opportunity, Treat analysis in Tawang Station Area}

Based on the results of the survey, the main strength of the station area is a public facility that became the main gate of the city. Weakness This area is an unintegrated with the old City of Semarang although it is a unit of historic area that actually can be an opportunity of this area. However, the area is potentially a land subsidence that can be a threat. Strength analysis, Weakness, Opportunity, deeper Treat can be seen in table 4

Table 4. Strength Weakness Opportunity and Treat analysis

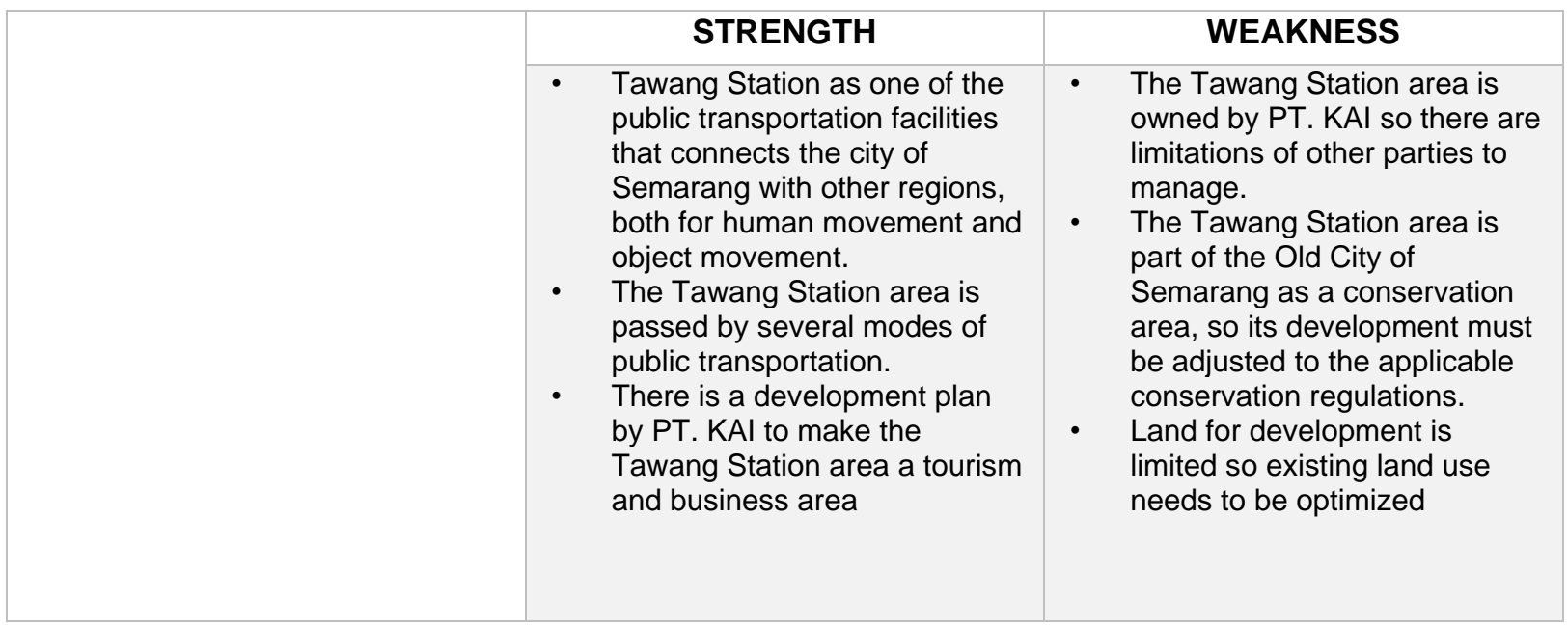




\section{OPPORTUNITY}

- The location of Tawang Station is strategic because it has a connection with the Old City of Semarang.

- Revitalization of the Old City of Semarang has been carried out so that it has an impact on the development of the Tawang Station area.

- There is an opportunity for the development of the tourism sector because of the polder tawang.

- The development of commercial facilities is very open because of its strategic location.

\section{S-O}

- Improved the function of the Tawang Station as a transportation facility by utilizing the strategic location of the tawang station.

- Optimizing open space oriented to the tourism sector.

- The development of the Tawang Station area into a tourism and business area by utilizing economic growth and increasing tourist numbers.

\section{W-O}

- $\quad$ Cooperation between PT. KAI, Semarang City Government, and the private sector in the development of the Tawang Station area which is integrated with the surrounding area, including in terms of conservation of cultural heritage buildings.

\section{THREATS}

- The Tawang Station area is prone to flooding and inundation.

- The Tawang Station area is a transportation hub for the city of Semarang, which has the potential for traffic congestion.

- Image Tawang Station area is bad because there are activities that are not in accordance with its function.

\section{S-T}

- Improving the quality of Tawang Station as a Semarang City transportation node to overcome traffic congestion.

- Design the Tawang Station area with a concept that is able to cope with flood and inundation disasters.

\section{W-T}

- Making disaster protection (providing irrigation pumps)

\subsection{Smart Urban Railway Space Concept in Tawang Station Area}

The Plaza in station should play a crucial role in the future in the new city space. The Plaza in front of the railway station area should be considered by city planners as an important place, which can have a flexible function and continue to act as an urban plaza even after the closure of certain stations (Kido, 2019). Urban Railway Space is an important visual and functional element of the station environment, as well as the Urbanscape (EBA, 2018). Currently, the project infrastructure development of Tawang area is only centered on the development of railway stations implemented by PT KAI which works together with local governments and residents are not involved as part of the city's rebuilding project. So, the development is less optimal. The polder in front of the Tawang station area should be considered as an important place that has crucial role in Tawang area development.

- Architecture and public space

Tawang polder is a strategic tourism attraction that bridges the Tawang station with the Old City area. Integrate open space (the Tawang Polder) area of Tawang station with Kota Lama can make Tawang station to be the entrance of tourists and tourism site. By maintaining the function of the polder as a retention pond and functioning it as a public recreation park, the polder has its own uniqueness (see Figure 8). This Polder became the connecting point of Tawang station in the old city area and became one of the main elements of the smart urban railway space concept. 

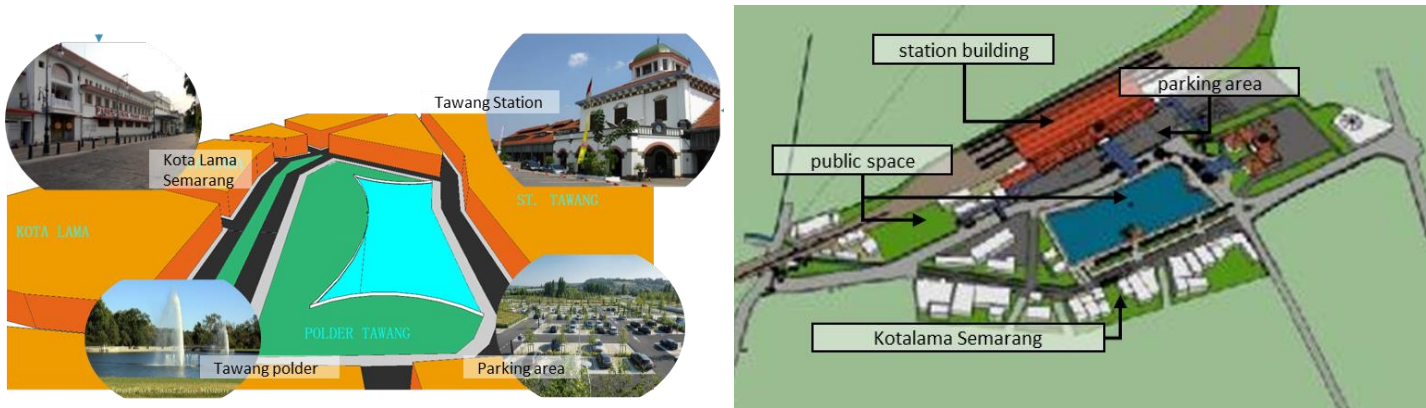

Figure 8. Design of Connecting Building and Public Space

\section{- Smart Mobility/integrated mobility}

A vehicle path that was previously through $\mathrm{Jl}$. Tawang in the switch through Jl. Merak. The toll road corridor in front of the station will be transformed into a parking area to parse Overcrowding happening on this road (see Figure 9). In addition, the circulation line becomes a bridge connecting the transportation room and the human mobility room.

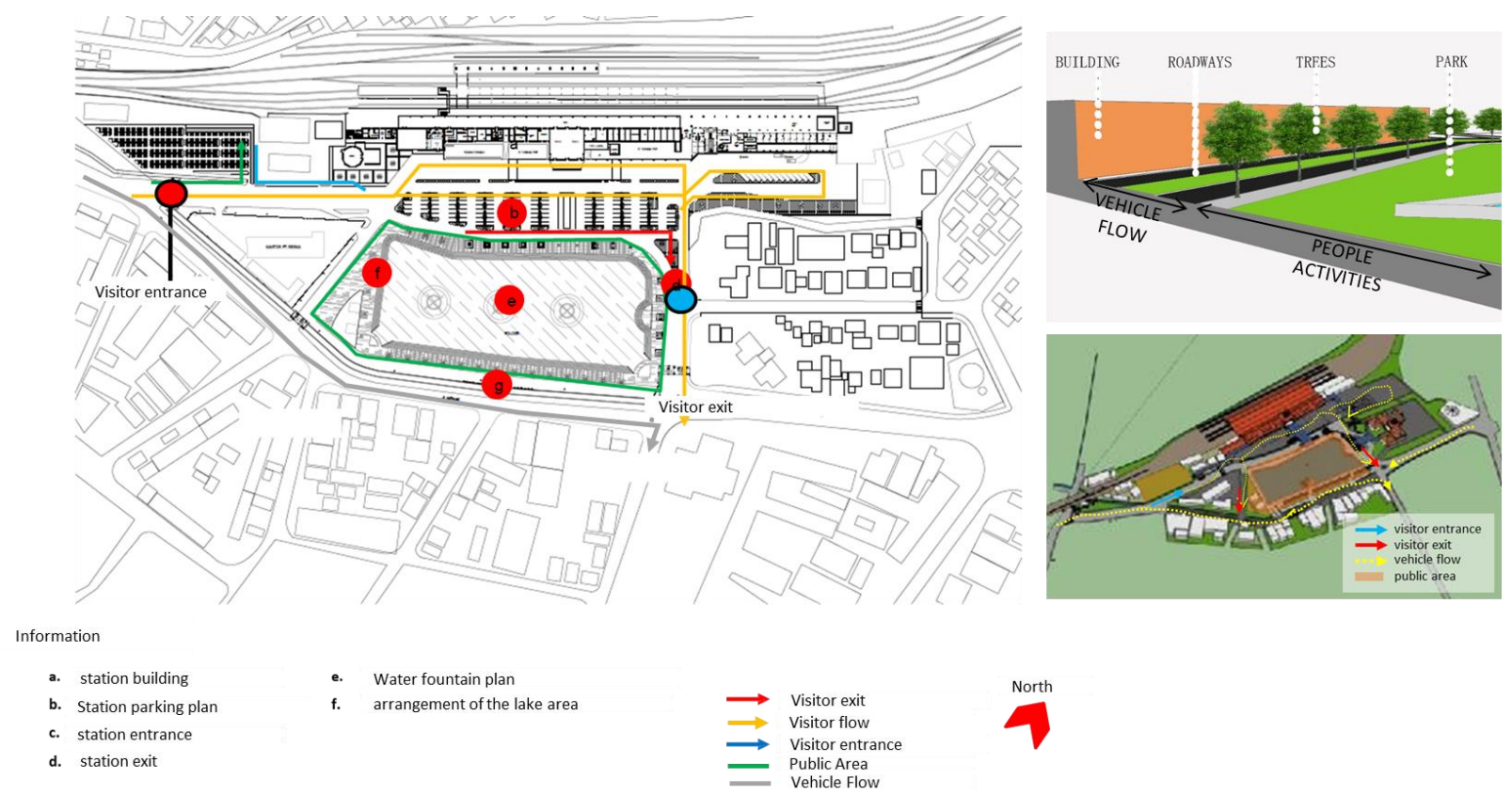

Figure 9. Rechange Circulation Flow to Reduce Overcrowding

- Adapting to all station users.

Newly faced design can take into account the various needs and expectations of various parties and stations users. Using materials "child-friendly, parents, people with disabilities and safe for all users. Appropriate signage and securing the installation of infrastructure. 


\section{Conclusion}

Tawang station is an important transportation center in the city of Semarang that can increase the city's economy from tourism. However, the increasing tourism visitors can also cause negative effects overcrowding. Overcrowding that is not well solved can paralyze the circulation of public transport. One way to reduce overcrowding is by planning a regionintegrated development with the surrounding environment and optimizing the potential for future planning. PT KAI itself has considered the development of this region to parse frequent overcrowding and optimizing poorly maintained areas. It is so so that the same is so that the previously well-maintained, cleanliness polder is controlled and maintained. The development of the area of Tawang station by PT KAI is covering the area of Tawang station, the Tawang Polder and housing PT Kai. Related to the development plan there are several pros and cons of practitioners, academics and community

\section{Recommendations}

The government and PT KAI should consider Tawang Station area (the railway station area, the space around the station, and the polder area) as an important urban asset. The area of Tawang station and Polder Tawang station is an important element in their urban structure and aesthetics, and its function is very important for local residents, as well as for the whole city. New developments will better reflect the identity of the environment-"sense of place". It also includes the preservation of architecture and historical structures that are a source of local characteristics. Implementing the concept of smart city on a station area is the core of the concept of smart urban railway space. This smart urban railway space is considered suitable as a concept that can optimize Tawang station area into a tourism place. Things to do when redesigning the area station Tawang to smart urban railway space is (1) Integrate the open Space Tawang Station area with the surrounding environment, (2) parse the overcrowding problem of visitors that occur at the time of the train arrival and departure, and (3) take into account the various needs and expectations of the users to the management and governance.

\section{Acknowledgments}

The author thanked the lecturer of Master of Architecture Program at Diponegoro University who always guide and give directions, on the subject of the city planning Studio. Practitioners and academics who are pleased in the interview as material consideration of the concept of Tawang station area. PT KAl is pleased to provide the development data of Tawang station area as a reference to the development of redesign concept. The surrounding community and visitors to the area of Tawang station have given their opinions so that we can analyse the potential of this region. As well as other uncredited parties, who have helped us to complete this journal.

\section{References}

Australian, T., \& Audit, I. (2019). Urban Transport Crowding and Congestion The Australian Infrastructure Audit 2019 Supplementary report (Issue June).

Badan Pusat Statistik. (2019). Statistik Daerah Kota Semarang 2019. In BPS Kota Semarang.

Crothers, C., Kearns, R. A., \& Lindsey, D. (1993). Housing in Manukau City: Overcrowding, poor housing and their consequences. University of Auckland, Department of Sociology.

Dinas Perhubungan Kota Semarang. (2018). Rencana Strategis (Renstra) Dinas Perhubungan Komunikasi dan Informatika Kota Semarang Tahun 2016-2021.

Ellisa, E. (2016). Coping with crowding in high-density kampung housing of Jakarta. ArchnetIJAR, 10(1), 195-212. https://doi.org/10.26687/archnet-ijar.v10i1.790

Furchan, A. (2004). Pengantar Penelitian Dalam Pendidikan. Yogyakarta: Pustaka Belajar. 
Galiza, R. J., Kim, I., Ferreira, L., \& Laufer, J. (2009). Modelling pedestrian circulation in rail transit stations using micro-simulation. 32nd Australasian Transport Research Forum, ATRF 2009, January.

Gerritsma, R. (2019). Overcrowded Amsterdam: striving for a balance between trade, tolerance and tourism. In C. Milano, J. M. Cheer, \& M. Novelli (Eds.), Overtourism: excesses, discontents and measures in travel and tourism (pp. 125-147). CAB International 2019. https://doi.org/10.1079/9781786399823.0125

Giffinger, R., Fertner, C., Kramar, H., Meijers, E., \& others. (2007). City-ranking of European medium-sized cities. Cent. Reg. Sci. Vienna UT, 1-12. http://www.smartcities.eu/download/smart_cities_final_report.pdf

Gove, W. R., Hughes, M., \& Galle, O. R. (1979). Overcrowding in the home: An empirical investigation of its possible pathological consequences. American Sociological Review, 59-80.

House of Commons Transport Committee. (2003). Overcrowding on Public Transport: Vol. I.

International Union of Railways. (2017). Smart stations in smart cities (Issue October). https://uic.org//MG/pdf/smart_stations_in_smart_cities.pdf

Jazwinski, C. (1998). Crowding. http://condor.stcloud.msus.edu/ jaz/psy373/7.crowding.html

Kido, E. M. (2019). Challenges of the New Urban Railway Space: Elevated Railroads and Station Plazas. Annual Report of RESCO, 17, 42-63.

Mackingtosh, E., West, S., \& Saegert, S. (1975). Two Studies of Crowding in Urban Public Spaces. Environment and Behavior, 7(2), 159-184. https://doi.org/10.1177/001391657500700203

Meytasari, C., \& Tisnawati, E. (2018). THE TOURISM ELEMENT PRODUCT DEVELOPMENT OF SEMARANG OLD CITY BASED ON ATTRACTIVE URBAN HERITAGE APPROACH. ARSITEKTURA, 16(1), 107-118.

Nugroho, A. N., \& Khadiyanta, P. (2015). Perancangan Ruang Fisik Kawasan Stasiun Tawang yang Terintegrasi dengan Angkutan Umum Kota Semarang. Ruang, 1(3), 121130.

Pinasthika, N., \& Pradoto, W. (2018). Potensi dan Tantangan Pengembangan Kawasan Kota Lama Semarang sebagai Destinasi Wisata dengan Pendekatan Smart Tourism. Teknik PWK (Perencanaan Wilayah Dan Kota), 7(3), 153-164.

Popp, M. (2012). Positive and negative urban tourist crowding: Florence, Italy. Tourism Geographies, 14(1), 50-72.

Sanjaya, A. (2018). Masukan Masterplan Smart City Kota Semarang. Proyek Bimbingan Teknis "Penyusunan Masterplan Smart City Semarang," August 2017. https://doi.org/10.13140/RG.2.2.27478.75844

Shirvani, H. (1985). The urban design process. Van Nostrand Reinhold Company.

Sukawi, S. (2008). Mencari Potensi Wisata Kota Lama Semarang. Jurnal Ilmiah Perancangan Kota Dan Permukiman, 7(1), 28-37.

Tokody, D., Schuster, G., \& Papp, J. (2015). Smart City, Smart Infrastructure, Smart Railway. International Conference on Applied Internet and Information Technologies 2015, $231-$ 234.

Weber, F., Stettler, J., Priskin, J., Rosenberg-Taufer, B., Ponnapureddy, S., Fux, S., \& Barth, M. (2017). Tourism destinations under pressure: Challenges and innovative solutions. Lucerne University of Applied Sciences and Arts Institute of Tourism ITW, Roesslimatte, 48,6002 . 